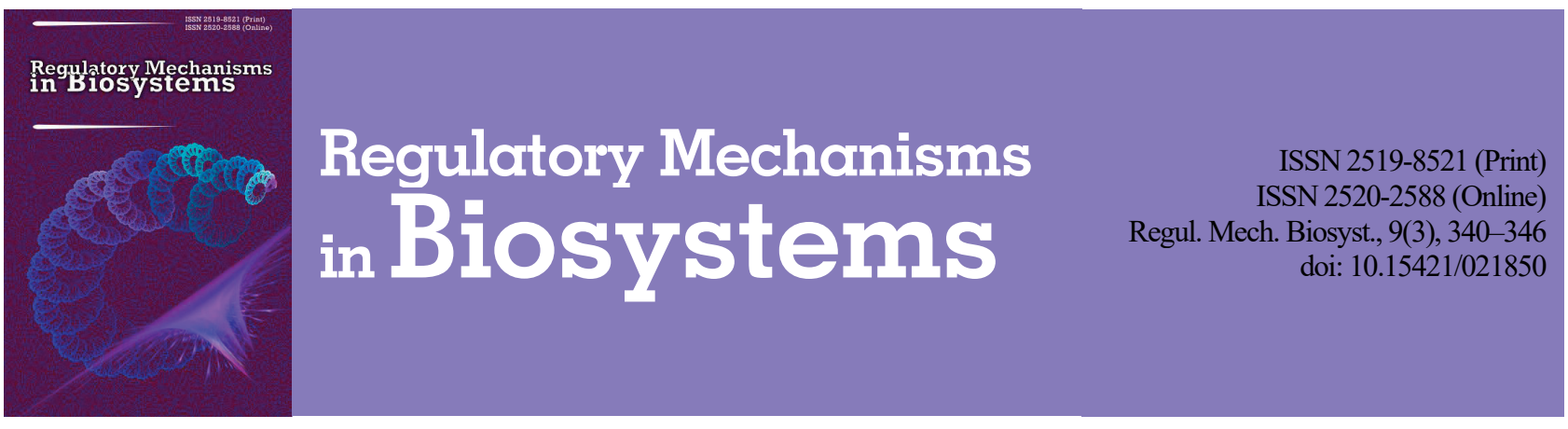

\title{
Effect of clonal reproduction on quantitative indices and component composition of essential oil of peppermint varieties
}

\author{
T. E. Talankova-Sereda*, J. V. Kolomiets*, A. F. Likhanov**, \\ A. V. Sereda***, N. I. Kucenko****, E. O. Shkopinskiy***** \\ *National University of Life and Environmental Sciences of Ukraine, Kyiv, Ukraine \\ **Institute for Evolutionary Ecology of NAS of Ukraine, Kyiv, Ukraine \\ ***Chinese-Ukrainian Life Sciences Research Institute, Zhuji City, China \\ ****Experimental Station of Medicinal Plants at the Institute of Agroecology and Nature Management of NAAS, Beresotocha, Ukraine \\ *****Zaporizhzhia National University, Zaporizhzhia, Ukraine
}

Article info

Received 14.06.2018

Received in revised form 20.07.2018

Accepted 28.07.2018

National University of Life and

Environmental Sciences of Ukrain

Heneral Rodimtsev st., 19/4,

Kyiv, 03041, Ukraine.

Institute for Evolutionary Ecology

NAS Ukraine, Lebedev st., 37,

Kyiv, 03143,Ukraine.

Sino-Ukrainian Institute of Life

Sciences, South Wenzhou st., 26

Zhuji City, Prov. Zhejiang

Republic of China.

Experimental Station of Medicinal

Plants at the Institute of

Agroecology and Nature

Management of NAAS,

Lenin ave., $16 a$

Beresotocha, 37535, Ukraine.

Zaporizhzhia National University Zhukovskogo st., 66,

Zaporizhzhya, 69600, Ukraine.

Tel.: + 38-050-983-58-53.

E-mail: tatazp77@gmail.com
Talankova-Sereda, T. E., Kolomiets, J. V., Likhanov, A. F., Sereda, A. V., Kucenko, N. I., \& Shkopinskiy, E. O. (2018). Effect of clonal reproduction on quantitative indices and component composition of essential oil of peppermint varieties. Regulatory Mechanisms in Biosystems, 9(3), 340-346. doi:10.15421/021850

Quantitative and qualitative composition of essential oils of peppermint breeds Lebedinaya Pesnya, Lubenchanka, Lidiya, Ukrainskaya Perechnaya, Mama, Chornolista was investigated before and after clonal microreproduction by the method of isolated tissues and bodies culture in vitro. Methods of essential oil steam distillation, capillary gas chromatography and statistical analysis were used in the research. It is established that increase in essential oil quantity was observed for peppermint breeds on which reproduction and improvement in vitro technology was applied. As a result of clonal microreproduction of peppermint plants in culture in vitro on nutrient medium Murasige and Skug, in which the growth regulators $0.75 \mathrm{mg} / \mathrm{l} \mathrm{of} \mathrm{6-}$ benzylaminopurine, $0.1 \mathrm{mg} / \mathrm{l}$ of adenine, $0.05 \mathrm{mg} / 1$ of indolil-3-acetic acid and $0.5 \mathrm{mg} / \mathrm{l}$ of gibberellins acid were added and virocide Ribavirin in concentration $10 \mathrm{mg} /$, improvement was obtained in comparison with vegetatively reproduced plants; increase in essential oil quantity per hectare was established for the following breeds; Chornolista by $54.2 \%$, Lebedinaya pesnya by $38.2 \%$, Ukrainskaya Perechnaya by $36.7 \%$, Mama by $28.5 \%$, Lubenchanka by $17.1 \%$ and Lidiya by $11.6 \%$. For oil content the highest indices were noted for Lubenchanka, Mama and Lebedinaya Pesnya peppermint breeds with product yield $4.02 \%$, $3.98 \%$ and $3.84 \%$ respectively. It was established that the essential oil component composition in non-clonal peppermint plants raw materials and plants-regenerants after culture in vitro is variable depending on breed. Limonene, cineole, menthone, menthofuran, iso-menthone, menthyl acetate, $\beta$-caryophyllene, iso-menthol, menthol, pulegone, germacren, piperitone, carvone were identified in peppermint essential oil. High content of menthol, low content of carvone, piperitone, pulegone (except for Chornolista, Ukrainskaya Perechnaya breeds) and menthofuran (except for Chornolista, Ukrainskaya Perechnaya and Lubenchanka breeds) are characteristic for Ukrainian selection peppermint investigated breeds. A clear tendency to menthol and menthone content ratio increase is observed in plants which were improved in conditions in vitro. Pulegone was not detected in essential oil samples of Lebedinaya Pesnya, Lidiya and Mama breeds. Biochemical markers of Lebedinaya Pesnya, Lubenchanka, Mama breeds, which differentiate them within the group of investigated breeds, are higher limonene, piperitone and menthol pool; for Ukrainskaya Perechnaya and Chornolista breeds - pulegone, cineole and menthone; for Lidiya breed - iso-menthone.

Keywords: Mentha piperita; in vitro; capillary gas chromatography; menthol; menthone; pulegone.

\section{Introduction}

According to State Statistics Service data nearly 50 species of plants whose raw materials are used for medicinal preparation manufacture are cultivated in Ukraine. Structural parts of these plants contain biologically active substances which positively influence the human organism. Peppermint is one of the most widespread and traditionally cultivated species. It is cultivated as industrial culture in all climatic zones of Ukraine, Moldova, Russia (Krasnodar territory and North Caucasus), Belarus, and also in many countries of Europe, Central Asia, Africa, India and the North America. Such soil-climatic variety of cultivation zones testifies to the considerable adaptive potential of this culture. The demand for medicinal preparations on the basis of natural vegetative raw materials has increased in the last $10-15$ years and the Ukraine home market does not satisfy the needs of the domestic chemical-pharmaceutical industry, which requires every year nearby 50 tonnes of $M$. piperita essential oil and 20-25 tonnes of natural menthol (Shelud'ko, 2004). Mint is a source for obtaining pharmaceutic leaf, essential oil and its components, which are widely used in the chemical-pharmaceutical, perfume-cosmetic, confectionery, food, liqueur and spirits, tobacco, paint and coatings industries and medicine (Vojtkevich, 1999; Tkachenko, 2011).

The biologically active substances of peppermint are complex and its essential oil shows anti-inflammatory, antimicrobial, antifungal, antiviral, anthelmintic, antiparasitic, analgetic, spasmolytic, cholagogic, mucolytic and broncholytic, antihistaminic action, normalises central and vegetative nervous system activity, limits rotting and fermentation processes, strengthens motor secretory intestinal tract function, prevents peptic ulcer development, expands coronary vessels, improves heart blood supply, reduces pressure in blood circulation small circle, and also shows 
antiarrhythmic and hypertensive action, improves sports results, attention, working memory, cognitive activity, visual motor reactions (Grigoleit \& Grigoleit, 2005; Mi-Hyun et al., 2005). The biologically active substances complex of mint oil is primarily responsible for the therapeutic action of peppermint. About 100 components are identified in mint essential oil according to Lawrence (2006), basic of which are menthol, and also $\alpha$-pinene, $\beta$-pinene, limonene, sabinene, isoamyl alcohol, phelandrene, 1.8-cineole, $\mathrm{\gamma}$-tarpinene cis-3-hexanol, trans-sabinene hydrate, menthone, menthofuran, isomenthone, menthyl acetate, neomenthol, terpinene-4-ol, caryophyllene, germacrene, dipentene, pulegone and other terpenoids. Monoterpenic alcohol menthol, the action of which is sufficiently selective, has substantial significance in the substances complex. The substance irritates first of all mucous membranes and skin thermoreceptors, which causes cooling sensation, which is accompanied by reflex vessels constriction, after which burning sensations develop and then easy anaesthesia comes (Magge \& Lembo, 2011). Thanks to such properties, peppermint is a part of many pharmaceutical preparations. Herbage, leaves and essential oil, concentration of which fluctuates in peppermint leaves according to Shelud'ko (2004) data from $1.2 \%$ to $4.8 \%$ and in inflorescences reaches $6.0 \%$, are used for their manufacturing.

The Mentha species breeds collection is collected, studied and registered in the National Centre of Genetic Resources in Ukraine. 269 samples are in the collection structure, from which over $11 \%$ belong to $M$. piperita L., and about $40 \%$ are hybrids which have been created in the course of selection research. The collection is stored in Experimental Station of Medicinal Plants of the Institute of Agroecology and Nature Management of National Academy of Agricultural Sciences (NAAS) of Ukraine and is used by selectionists in creation of new breeds with better essential oil indices (Kolosovich et al., 2008). Five pepper mint grades are registered in the Register of Breeds Suitable for Distribution in Ukraine (Derzhavnij reestr sortiv roslyn pridatnyh do poshyrennja v Ukrajini, 2016). The majority of priority breeds, except the breed Lada, were created 10 and more years ago. Considering that pepper mint breeds are bred in vegetative way, a decrease in their raw productivity is marked during the long period of their cultivation. It is known that the essential oil quantity and quality in raw materials depends on a plant organs proportion, age, climatic conditions, agricultural techniques, extra nutrition, degree of contamination and protection systems. In Brazil, research by Costa et al. (2013) with colleagues revealed that various organic amendments sources and influence of doses on plants and essential oil biomass manufacture, changes in menthone, pulegone and menthyl acetate quantitative composition were observed in essential oil chemical composition, although menthol indices were stable. Growth regulators at application on a green leaf differently influence pepper mint essential oil productivity and qualitative characteristics. Salicylic acid turned out to be the best for increase in quantity yield of oil, concentration of menthol and menthyl acetate in $M$. piperita, 6-benzylaminopurine (BAP) increased yield of menthone; gibberellic acid (GA) increased menthyl acetate content (Dmitrieva \& Dmitriev, 2011; Khanam \& Mohammad, 2017).

It is established on the basis of research by Mishhenko et al. (2016) in the joint work of the Viruses Ecology and Virus Diseases Diagnostics Research Laboratory of the Education Scientific Centre "Biology Institute" of Taras Shevchenko National University of Kyiv with colleagues of National University of Bioresources and Nature Management of Ukraine and the Research Sstation of Medicinal Plants of the Institute of Agroecology and Nature Management of NAAS of Ukraine that over the last $10-15$ years peppermint has been affected by 23 viruses, in particular on the territory of Ukraine $\mathrm{P}$. virus $\mathrm{Y}, \mathrm{P}$. virus $\mathrm{X}$ and an unidentified filariform virus, which considerably reduces the quality of the raw materials, owing to such symptoms arising as growth inhibition, lamina deformity, leaf curl, savoyed leaf and frenching. Certified seeds improvement by the apical meristems method and chemotherapy, which is based on explants cultivation in vitro on nutrient mediums with viricides addition, is one of the most effective ways to combat the viruses (Mel'nichuk et al., 2003).

Santoro et al. (2013) has shown that addition of BAP to nutrient medium Murasige and Skug (MS) in concentration of $0.6 \mathrm{mg} / 1$ increases the general essential oil yield and some its components: menthone, menthol, pulegone and menthofuran by secondary metabolites biosynthesis induction. It is shown in the research of Slovak scientists that in the essential oil composition of $M$. piperita breed Kristinka in culture in vitro the menthofuran content increased after addition of 2,4-dichlorophenoxyacetic acid (2,4-D) and $\mathrm{CoCl}_{2}$ to the nutrient medium and after BAP and zeatin application pulegone content increased (Fejer et al., 2018).

Therefore, the topicality of the given work consists in studying for plants at clonal microreproduction in vitro the influence of the improvement process on the further secondary metabolites synthesis, in particular terpenoids, which are a part of the essential oils of mint. In this connection, the purpose of our work is to investigate within three years the quantitative content and qualitative composition of essential oil components of peppermint breeds of the Ukrainian selection Lebedina Pisnya, Lubenchanka, Lidiya, Ukrainska Perechna, Mama, Chornolista, received from plants after vegetative reproduction and clonal microreproduction in vitro.

\section{Materials and methods}

The research objects are the essential oil samples of pepper mint breeds Lebedina Pisnya (5), Lubenchanka (7), Lidiya (8), Ukrainska Perechna (9), Mama (10), Chornolista (11). The breed Lebedina Pisnya is cultivated for obtaining pharmaceutic leaves and for essential oil processing. The breed Lubenchanka is cultivated for pharmaceutical industry technical purposes - obtaining essential oil and menthol. The breeds Lidiya, Chornolista, Mama are used for obtaining pharmaceutic leaves (Grodzins'kij, 1992; Shelud'ko, 2004).

The research was conducted during 2014-2017 within the framework of the scientific theme "Lamiaceae family essential oil medicinal plants. Biotechnological reproduction foundations for receiving high-quality planting material"' (number of the state registration 0116U001994).

Methods of isolated tissues and organs culture in vitro and chemotherapy were used for pepper mint improvement in 2014. Murashige and Skoog (Murashige \& Skoog, 1962) nutrient medium, in which $0.75 \mathrm{mg} / \mathrm{l}$ BAP, $0.1 \mathrm{mg} / \mathrm{l}$ adenine, $0.05 \mathrm{mg} / \mathrm{l}$ indolebutyric acid (IAA) and $0.5 \mathrm{mg} / \mathrm{l}$ gibberellic acid (GA), and also virucide Ribavirin (1- $\beta$-D-ribofuranosyl-1,2,4-triazole-3-carboxamide, "Sigma-Aldrich", USA) in $10 \mathrm{mg} / \mathrm{l}$ concentration were added, paravariation was used for above mentioned peppermint breeds of Ukrainian selection explants introduction and microreproduction (Talankova-Sereda et al., 2016).

The experiment was conducted four times in Lubensky district of Poltava region in the territory of the Research Station of Medicinal Plants of the Institute of Agroecology and Nature Management of NAAS of Ukraine annually since 2015 in field conditions, in which the influence of clonal microreproduction and chemotherapy was investigated on the quantitative indices and componental composition of essential oil of pepper mint breeds Lebedina Pisnya, Lubenchanka, Lidiya, Ukrainska Perechna, Mama, Chornolista. Vegetatively reproduced planting material of the mint breeds was used as the control variants. Mint sprouts, which were used for trial establishment, met the requirements of the standard document "Mint Sprouts" (Technic Specifications 10-04-13-48-88 "Mint Sprouts. Technic Specifications").

The research was conducted according to Moloc'kij et al. (2006), Eshhenko et al. (2014), Shelud'ko \& Kucenko (2013) techniques. Pepper mint raw materials for obtaining essential oil were selected annually with time requirements compliance, which is defined in technology regulations for the investigated kind. In particular, the investigated breeds overground part was cut in the mass flowering phase as numerous researches specify a tendency to increase in essential oil content during this period (Tanasienko, 1985; Kirichenko, 2008; Morozov \& Hazieva, 2013). Raw materials from plants after vegetative reproduction and plants to which clonal microreproduction in vitro was applied were selected on each of plots with the use of the linear metre method.

Essential oil was received by steam distillation by A. S. Ginzberg's technique (Hefendehl et al., 1967) with the subsequent recalculation on dry weight. For this purpose, $50 \mathrm{~g}$ milled raw materials were placed in wide neck flask with $3,000 \mathrm{ml}$ capacity, then $1,500 \mathrm{ml}$ water was added and it was closed with a rubber stopper with a ball check refrigerator. The calibrated receiver was suspended on metal hooks on the stopper 
underside in such way that the refrigerator end was directly under the receiver funneled widening on distance of about $1-2 \mathrm{~mm}$. The receiver was not less than on $50 \mathrm{~mm}$ from the water level. A flask with contents was heated up to boiling and the boiling was sustained for 1.5 hours. Water steam and essential oil after condensation in the refrigerator flowed down into the receiver in liquid form. Essential oil remained in the receiver's graduated knee, and water through a smaller receiver knee followed back into the flask. Essential oil volume in the receiver was measured after cooling the device and essential oil content was measured in volume-mass percent in relation to air-dry medicinal raw materials weight.

Essential oil received from pepper mint breeds Lebedina Pisnya, Lubenchanka, Lidiya, Ukrainska Perechna, Mama and Chornolista plants was a transparent liquid, light-yellowish colour, with a strong menthol smell, which remained in the glassware in the refrigerator at temperature $4{ }^{\circ} \mathrm{C}$.

The essential oil components analysis was conducted by the capillary gas chromatography method on chromatograph Agilent 7890A with flame ionization detector with automatic test input. A column: DBWAX (Agilent) $60 \mathrm{~g} * 0.25 \mathrm{~mm}$, an immovable phase macrogol 20000 ( 0.25 um). Carrier-gas: helium $1.5 \mathrm{ml} / \mathrm{min}$, stream division $1: 50$. For chromatography $25 \mathrm{mcl}$ essential oil was dissolved in $1.5 \mathrm{ml} \mathrm{n}$-hexane, injecttion volume: $1 \mathrm{mcl}$. Chromatography program: column temperature 15 minutes at $70^{\circ} \mathrm{C}$, then rise in temperature to $240^{\circ} \mathrm{C}$ over 85 minutes and kept for 5 minutes at $240{ }^{\circ} \mathrm{C}$; the block of tests input $-250^{\circ} \mathrm{C}$, the detector $-270{ }^{\circ} \mathrm{C}$.

Components identification was conducted by comparison of the chromatogramms with typical mint oil chromatogramm which meets the requirements of monography EP "Peppermint oil" (Ph. Eur. 8, 2014). Calculation of percentage components proportion was performed by the method of internal normalisation of essential oil composition and these results were compared with corresponding intact plants.

Statistically average values and their standard errors are shown in the text and tables $(x \pm S E)$. The results were statistically processed with the help of the program Statistica 7.0 (StatSoft Inc., USA). Differences between average values were calculated by the method ANOVA.

\section{Results}

The highest indices of essential oil content among investigated pepper mint breeds of Ukrainian selection were noted for Lubenchanka, Mama and Lebedina Pisnya $-4.02 \%, 3.98 \%$ and $3.84 \%$ respectively (Table 1 ). These indices are especially important for breeds Lubenchanka and Lebedina Pisnya, which are cultivated for obtaining essential oil as the basic product.

\section{Table 1}

Essential oil content (\%) in medicinal peppermint breeds of the Ukrainian selection raw materials $(2015-2017, \mathrm{n}=5, \mathrm{x} \pm \mathrm{SE})$

\begin{tabular}{|c|c|c|c|c|}
\hline $\begin{array}{c}\text { Peppermint } \\
\text { breeds }\end{array}$ & Variants & 2015 & 2016 & 2017 \\
\hline Lebedina & VR & $3.79 \pm 0.010$ & $3.82 \pm 0.013$ & $3.82 \pm 0.006$ \\
\hline Pisnya & in vitro & $3.83 \pm 0.013^{* *}$ & $3.85 \pm 0.008^{*}$ & $3.85 \pm 0.008^{* *}$ \\
\hline \multirow{2}{*}{ Lubenchanka } & VR & $3.98 \pm 0.008$ & $4.01 \pm 0.014$ & $3.99 \pm 0.010$ \\
\hline & in vitro & $4.00 \pm 0.013$ & $4.03 \pm 0.017$ & $4.02 \pm 0.015^{*}$ \\
\hline \multirow{2}{*}{ Lidiya } & VR & $3.20 \pm 0.013$ & $3.24 \pm 0.016$ & $3.23 \pm 0.013$ \\
\hline & in vitro & $3.33 \pm 0.010^{* *}$ & $3.35 \pm 0.008^{* *}$ & $3.34 \pm 0.017^{* *}$ \\
\hline Ukrainska & VR & $3.63 \pm 0.014$ & $3.67 \pm 0.013$ & $3.63 \pm 0.015$ \\
\hline Perechna & in vitro & $3.66 \pm 0.010$ & $3.71 \pm 0.014^{* *}$ & $3.70 \pm 0.010^{* *}$ \\
\hline \multirow{2}{*}{ Mama } & VR & $3.90 \pm 0.013$ & $3.94 \pm 0.008$ & $3.91 \pm 0.010$ \\
\hline & in vitro & $3.95 \pm 0.010^{* *}$ & $3.99 \pm 0.010^{* *}$ & $3.99 \pm 0.008^{* *}$ \\
\hline \multirow{2}{*}{ Chornolista } & VR & $3.74 \pm 0.014$ & $3.78 \pm 0.010$ & $3.77 \pm 0.013$ \\
\hline & in vitro & $3.81 \pm 0.016^{* *}$ & $3.86 \pm 0.013^{* *}$ & $3.83 \pm 0.010^{* *}$ \\
\hline
\end{tabular}

Notes: VR - vegetatively reproduced plants; in vitro - plants treated in culture in vitro; ${ }^{*}$ - differences are statistically signicant at $\mathrm{P}<0.05,{ }^{*} *_{-}$at $\mathrm{P}<0.01$ comparing with the control.

The Lidiya breed of vegetative reproduced plants contained the least essential oil quantity $3.22 \%$, however this index increased by $0.12 \%$ in plants after culture in vitro and was 3.34\%. Essential oil quantity in vegetatively reproduced plants of the breed Ukrainska Perechna after culture in vitro was accordingly $3.64 \%$ and $3.69 \%$. It is important also, that plants of this breed in culture in vitro had the maximum rate of reproduction 1:15 for one passage. Essential oil quantity in vegetatively reproduced plants of breed Chornolista was $3.77 \%$, and in plants after culture in vitro it increased to $3.83 \%$. It is necessary to note that the breed Chornolista is recognised by the State Commission of Strain Test in Ukraine as a peppermint meeting the state standard for the purpose of obtaining pharmaceutic leaves and manufacturing phytocompositions.

Essential oil componental composition and its separate fractions proportion are defined for peppermint breeds Lebedina Pisnya, Lubenchanka, Lidiya, Ukrainska Perechna, Mama and Chornolista. Limonene, cineole, menthone, menthofuran, isomenthone, menthyl acetate, $\beta$-caryophyllene, isomenthol, menthol, pulegone, germacrene, piperitone, carvone were identified among compounds which are components of pepper mint essential oil (Table 2, 3).

Table 2

Essential oil componental composition (\%) in peppermint breeds of the Ukrainian selection without culture in vitro application (2016)

\begin{tabular}{|c|c|c|c|c|c|c|c|}
\hline \multirow[b]{2}{*}{$\begin{array}{l}\text { Essential oil } \\
\text { component }\end{array}$} & \multirow[b]{2}{*}{$\begin{array}{c}\text { European } \\
\text { Pharma- } \\
\text { copoeia } \\
\text { standard }\end{array}$} & \multicolumn{6}{|c|}{ Peppermint breeds } \\
\hline & & 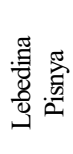 & 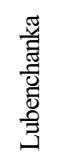 & 莤 & 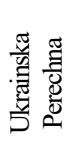 & 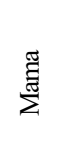 & 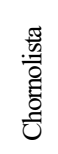 \\
\hline Limonene & $1.0-5.0$ & 3.2 & 3.5 & 1.3 & 0.9 & 3.2 & 1.1 \\
\hline Cineole & $3.05-14.0$ & 0.2 & 0.3 & 0.1 & 2.8 & 0.2 & 3.8 \\
\hline Menthone & $14.0-32.0$ & 14.9 & 9.3 & 12.6 & 18.8 & 12.6 & 23.5 \\
\hline Menthofuran & $1.0-9.0$ & 0.5 & 4.4 & 0.0 & 9.3 & 0.5 & 4.8 \\
\hline Isomenthone & $1.5-10.0$ & 2.8 & 2.5 & 17.6 & 5.3 & 2.7 & 4.0 \\
\hline $\begin{array}{l}\text { Menthyl } \\
\text { acetate }\end{array}$ & $2.8-10.0$ & 2.4 & 3,3 & 2.9 & 8.5 & 2,6 & 3.1 \\
\hline Menthol & $30.0-55.0$ & 70.1 & 68.0 & 60.5 & 38.4 & 72.0 & 30.7 \\
\hline Isomenthol & - & 2.0 & 3.1 & 1.1 & 2.5 & 2.0 & 6.5 \\
\hline Pulegone & Up to 4.0 & 0.0 & 0.0 & 0.0 & 6.1 & 0.0 & 11.1 \\
\hline Carvone & Up to 1.0 & 0.0 & 0.1 & 0.2 & 0.1 & 0.0 & 0.6 \\
\hline $\begin{array}{l}\text { Minor } \\
\text { compounds }\end{array}$ & - & 3.8 & 5.5 & 3.9 & 7.4 & 4.2 & 11.0 \\
\hline
\end{tabular}

Table 3

Essential oil componental composition (\%) in peppermint breeds of the Ukrainian selection after culture in vitro (2016)

\begin{tabular}{|c|c|c|c|c|c|c|c|}
\hline \multirow[b]{2}{*}{$\begin{array}{l}\text { Essential oil } \\
\text { component }\end{array}$} & \multirow[b]{2}{*}{$\begin{array}{c}\text { European } \\
\text { Pharma- } \\
\text { copoeia } \\
\text { standard }\end{array}$} & \multicolumn{6}{|c|}{ Peppermint breeds } \\
\hline & & 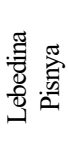 & 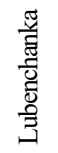 & 䞤 & 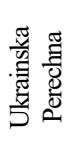 & $\begin{array}{l}\text { 营 } \\
\sum\end{array}$ & 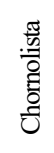 \\
\hline Limonene & $1.0-5.0$ & 2.9 & 3.5 & 1.5 & 0.7 & 1.9 & 1.0 \\
\hline Cineole & $3.1-14.0$ & 0.2 & 0.3 & 0.1 & 3.3 & 0.5 & 3.1 \\
\hline Menthone & $14.0-32.0$ & 8.8 & 8.9 & 11.0 & 20.1 & 12.9 & 21.8 \\
\hline Menthofuran & $1.0-9.0$ & 0.3 & 3.8 & 0.2 & 6.8 & 0.3 & 4.5 \\
\hline Isomenthone & $1.5-10.0$ & 2.8 & 2.8 & 16.8 & 6.8 & 1.5 & 3.3 \\
\hline $\begin{array}{l}\text { Menthyl } \\
\text { acetate }\end{array}$ & $2.8-10.0$ & 3.7 & 3.1 & 2.8 & 5.8 & 1.0 & 2.9 \\
\hline Menthol & $30.0-55.0$ & 74.1 & 68.8 & 61.4 & 44.2 & 72.6 & 33.3 \\
\hline Isomenthol & - & 2.0 & 2.8 & 1.2 & 2.5 & 4.3 & 6.4 \\
\hline Pulegone & up to 4.0 & 0.0 & 0.0 & 0.0 & 3.1 & 0.0 & 11.9 \\
\hline Carvone & up to 1.0 & 0.0 & 0.2 & 0.2 & 0.1 & 0.2 & 0.9 \\
\hline $\begin{array}{l}\text { Minor } \\
\text { compounds }\end{array}$ & - & 5.1 & 5.8 & 4.8 & 6.7 & 4.8 & 11.0 \\
\hline
\end{tabular}

Breeds Lebedina Pisnya - 70.1-74.1\% (Fig. 1), Lubenchanka $68.0-68.8 \%$, Lidiya $-60.5-61.4 \%$ and Mama $-72.0-72.6 \%$ contain the maximum menthol content as the basic marking essential oil component according to the received data.

Essential oil contained almost half the abovementioned content of menthol , 38.4-44.2\% and 30.7-33.3\% , respectively in vegetatively reproduced after culture in vitro breeds Ukrainska Perechna and Chornolista plants, which correlates with the high menthone content in these samples. The proportion of menthone was $18.8 \%$ in the essential oil of plants of the breed Ukrainska Perechna without culture in vitro application, after clonal microreproduction $-20.1 \%$, and in the breed Chorno- 
lista $-23.5-21.8 \%$, but total menthol and menthone content in these plants was high enough and was in the breed Ukrainska Perechna $57.2-64.3 \%$, Chornolista $-54.1-55.0 \%$. Total menthol and menthone content in high menthol breeds was considerably higher, in particular in Lebedina Pisnya $-85.0-82.9 \%$, Lubenchanka $-77.3-77.7 \%$, Lidiya $73.1-72.3 \%$ and Mama $-85.5-82.5 \%$.

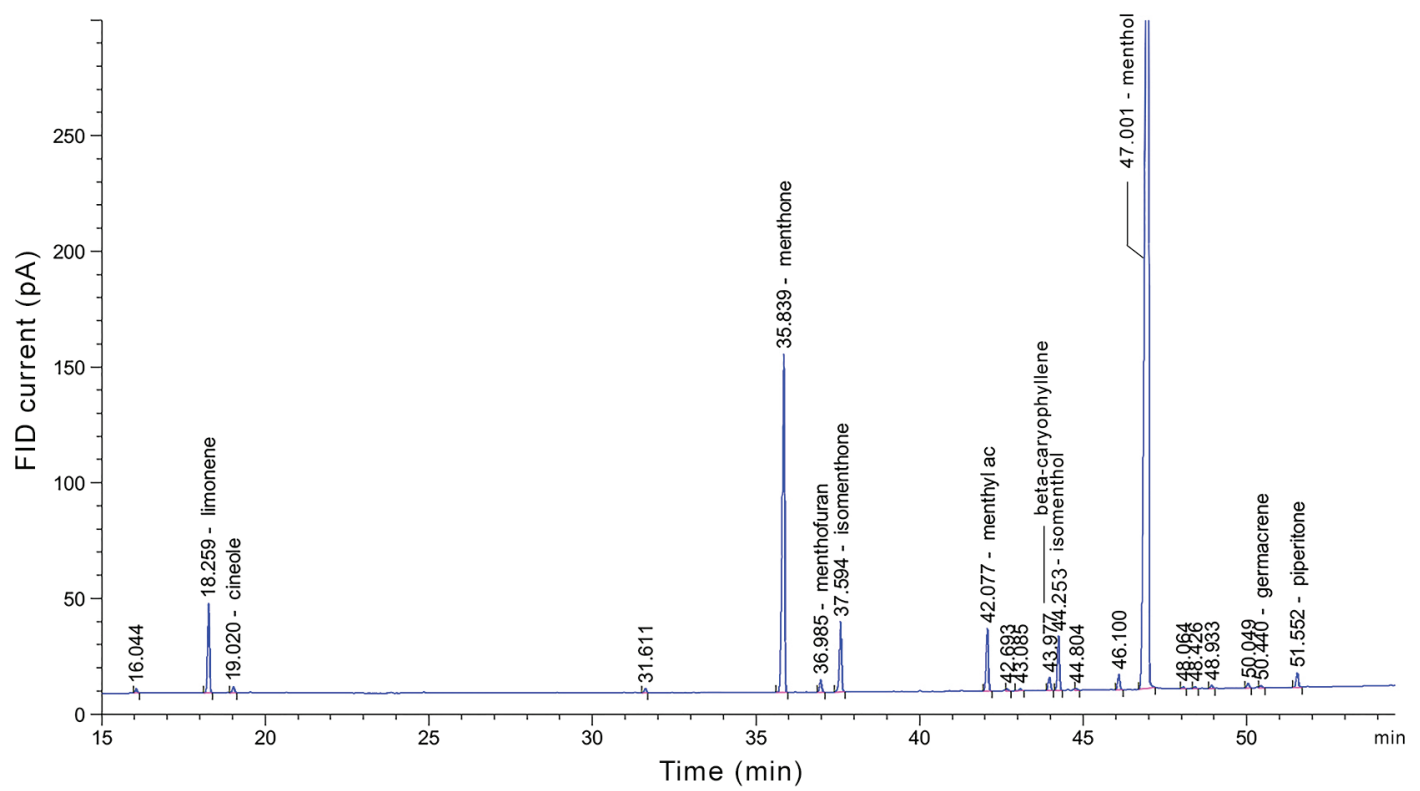

$a$

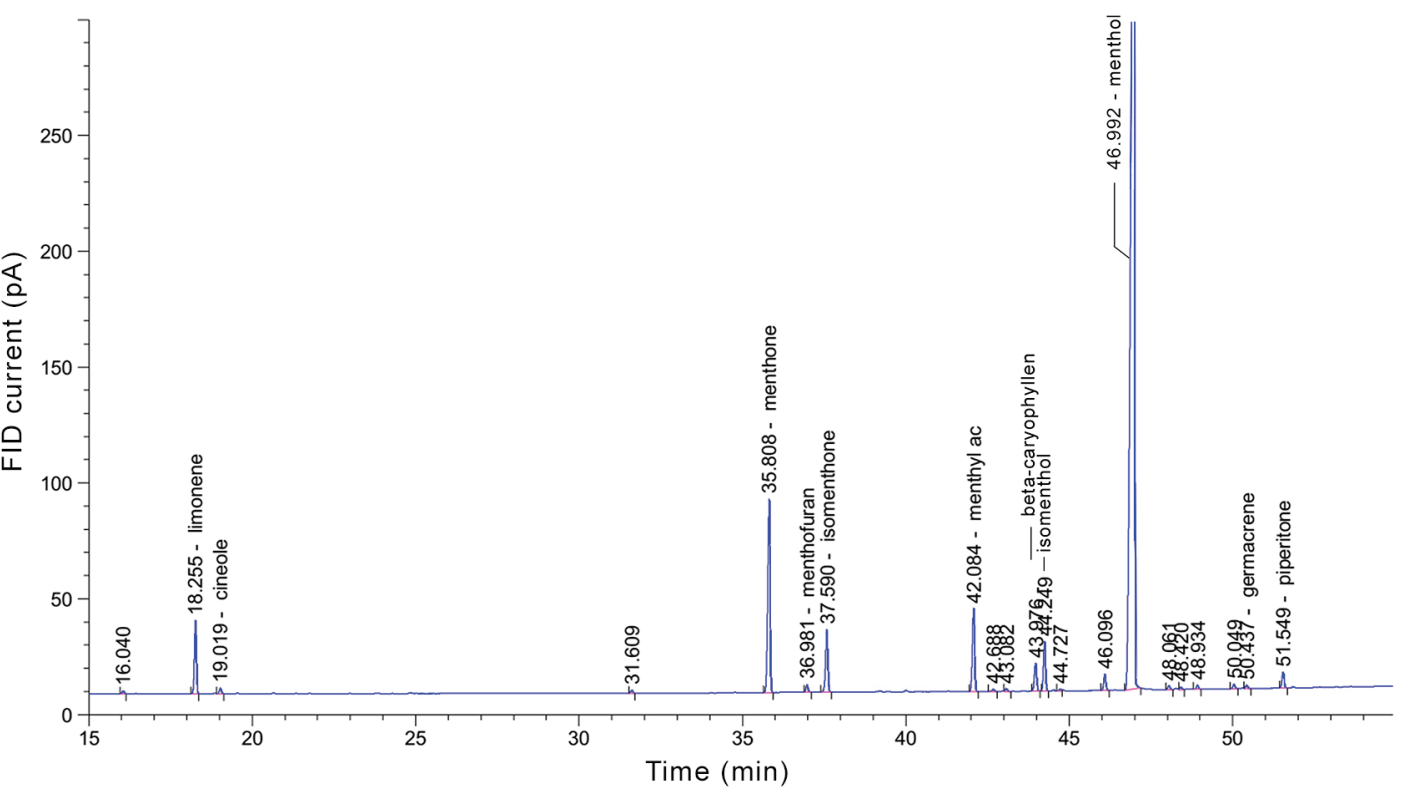

Fig. 1. Essential oil peppermint breed Lebedina Pisnya leafage chromatogram before in vitro $(a)$ and after in vitro $(b)$

Limonene concentration in all essential oil samples was within the range of the recommended European pharmacopoeia (Ph. Eur.) values, under which requirements this non-toxic monocyclic terpene representtative should be in the range of $1.0-5.0 \%$. Only in both essential oils of plant samples of the breed Ukrainska Perechna was it was lower than the European Pharmacopoeia standard by $0.1-0.4 \%$ (Ph. Eur. 8, 2014). The insignificant reduction in this essential oil component was observed in all pepper mint plants breeds after culture in vitro application by 0.1 $1.3 \%$, except for the breed Lidiya in which the proportion of limonene increased by $0.3 \%$.

Analysis of the amount of cineole contained in the essential oil samples showed that for the majority of breeds this component amounted to less than 1\%, except for two breeds - Ukrainska Perechna and Chornolista, but its quantity nevertheless is below European pharmacopoeia requirements. Only the essential oil which was received from vegetatively reproduced plants of the breed Chornolista corresponded to the European pharmacopoeia standards (3.5-14.0\%) (Ph. Eur. 8, 2014).
Menthone quantity decreased in essential oil of four breeds of vegetatively reproduced plants and after culture in vitro, in particular in the pepper mint breed Lebedina Pisnya by $6.15 \%$. In the breeds Ukrainska Perechna and Mama it slightly increased. The quantity of such major essential oil components as menthol and menthone in different breeds fluctuated. 
oil quality, but usually it is accompanied by other substances with an unpleasant smell.

Essential oil of the uncloned breed Ukrainska Perechna had increased pulegone content $-6.1 \%$, at the same time in this breed essential oil of plants after culture in vitro content of this component decreased by $50 \%$, which corresponds to the European pharmacopoeia requirements. In essential oil samples of vegetatively reproduced plants of the breed Chornolista, pulegone amounted to $11.1 \%$ and after culture in vitro application its content increased to $11.9 \%$, but such quantity exceeds European pharmacopoeia standards by three times (to 4\%). These breeds were created in Ukraine as English peppermint analogues, and pulegone presence is a characteristic feature for them, and its content, according to our data, considerably varies depending on weather conditions, collecting period of raw materials and other factors. Essential oil of pepper mint samples of other breeds of Ukrainian selection, Lebedina Pisnya, Lubenchanka, Lidiya and Mama did not contain pulegone at all, which in excessive quantity (more than $4 \%$ ) introduces an appreciable shade of standard English peppermint aroma.

All pepper mint essential oil plants of Ukrainian selection samples correspond to European pharmacopoeia standards for content of the terpenoids carvone and piperitone, and in the essential oil of pepper mint breed Mama, to which culture in vitro was not applied, and of the pepper mint breed Lebedina Pisnya (Fig. 1) carvone, which can give unpleasant caraway aroma to the essential oil and which under European pharmacopoeia recommendations should have a concentration of no more than $1 \%$, was completely absent. The low carvone content is a characteristic feature for all pepper mint breeds investigated by us.

Cineole/limonen proportion is an important peppermint essential oil quality index. Two breeds among the investigated essential oil samples correspond to European pharmacopoeia requirements. For Ukrainska Perechna without culture in vitro application this index is 2.9 and after culture in vitro application - 5.0, and also in breed Chornolista 3.5 - in uncloned plants and 3.0 - in plants after culture in vitro. According to $\mathrm{Ph}$. Eur. this proportion should be more than 2.0.

If total marking of mint essential oil compounds content will be counted in all essential oil samples, specifically menthone, isomenthone, menthol and isomenthol, it is possible to arrange breeds in such sequence as: Lidiya - 90.3-91.7\%; Mama - 89.3-90.3\%; Lebedina Pisnya 87.7-89.8\%; Lubenchanka - 82.9-83.2\%; Chornolista - 61.3-64.5\%, Ukrainska Perechna-61.6-64.9\%.

Main components analysis of qualitative composition and isoprenoid content in pepper mint breeds Lebedina Pisnya (5), Lubenchanka (7), Lidiya (8), Ukrainska Perechna (9), Mama (10), Chornolista (11) leaves established that the first main components axis (F1) was $58.4 \%$ from the general dispersion in indices complex, from which the greatest value was for menthol, pulegone, cineole. A slightly smaller contribution to the general dispersion is noted on menthone, germacrene, carvone and limonene content indices (Table 4).

Table 4

Main components analysis indices

\begin{tabular}{llll}
\hline \multirow{2}{*}{ Essential oil indices } & \multicolumn{3}{c}{ Main components weighting } \\
\cline { 2 - 4 } & $\mathrm{F}_{1}$ & $\mathrm{~F}_{2}$ & $\mathrm{~F}_{3}$ \\
\hline Limonene & $0.589^{*}$ & 0.261 & 0.054 \\
Cineole & $0.889^{*}$ & 0.003 & 0.058 \\
Menthone & $0.826^{*}$ & 0.006 & 0.001 \\
Menthofuran & 0.453 & 0.037 & $0.455^{*}$ \\
Isomenthone & 0.004 & $0.595 *$ & 0.329 \\
Menthyl acetate & 0.141 & 0.315 & $0.435^{*}$ \\
B-caryophyllene & 0.302 & 0.226 & 0.044 \\
Isomenthol & $0.569 *$ & 0.370 & 0.006 \\
Menthol & $0.944 *$ & 0.036 & 0.002 \\
Pulegone & $0.936^{*}$ & 0.033 & 0.001 \\
Germacrene & $0.678^{*}$ & 0.012 & 0.003 \\
Piperitone & $0.392^{*}$ & 0.247 & 0.261 \\
Carvone & $0.602^{*}$ & 0.131 & 0,182 \\
Minor compounds & $0.852^{*}$ & 0.055 & 0.003 \\
\hline
\end{tabular}

Notes: * - the greatest contribution to main components weighting.

Axis $F_{1}$ separates cloned and not cloned in vitro breeds Ukrainska Perechna and Chornolista from Lebedina Pisnya, Lubenchanka, Lidiya and Mama. The last differ by absence of pulegone in the leaves and rather high menthol content, which is the key vegetative raw materials quality feature. For breeds Ukrainska Perechna and Chornolista, the rather high menthone content accumulation, on the contrary, is characteristic. The second main components axis $\left(\mathrm{F}_{2}\right)$ was $16.6 \%$ from the general dispersion in which the greatest value was for isomenthone. In the investigated breeds group second components axis separates breeds Lidiya and Ukrainska Perechna. Axis $\mathrm{F}_{3}$ is $25 \%$ from the general dispersion. Menthofuran and menthyl acetate have the greatest value by the third component. The total 1 and 2 main components dispersion is $75 \%$ (Fig. 2). Biplot analysis use allows us to show a number of indices which characterise the investigated breeds by essential oil componental composition specificity.

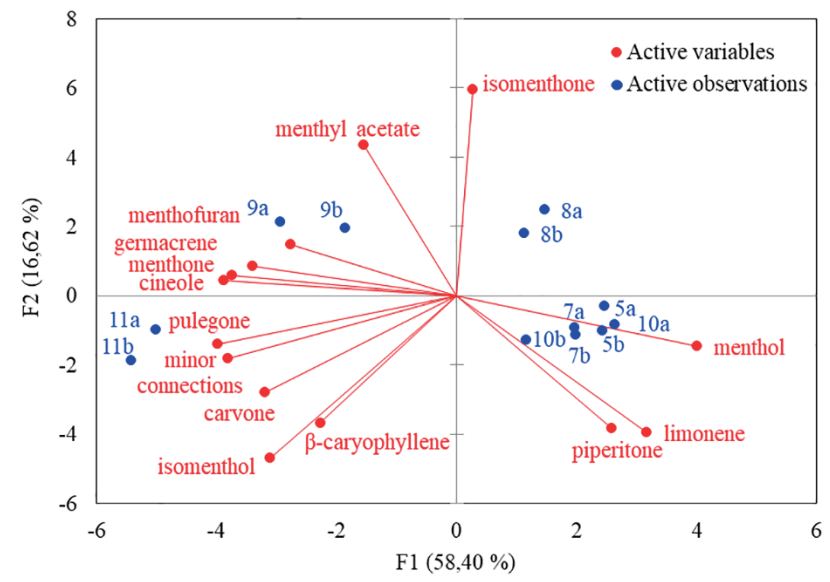

Fig. 2. Vegetatively reproduced plants $(a)$, and after clonal microreproduction $(b)$ pepper mint breeds Lebedina Pisnya (5),

Lubenchanka (7), Lidiya (8), Ukrainska Perechna (9), Mama (10), Chornolista (11) biplot analysis

It is established that in the Lebedina Pisnya, Lubenchanka, Mama breeds the predominate components which differentiate them within the group of investigated breeds, are limonene, piperitone, menthol; for Ukrainska Perechna and Chornolista breeds - pulegone, cineole and menthone; for Lidiya breed - iso-menthone.

\section{Discussion}

Essential oil composition is genetically caused. However the proportion of its components depends on many factors, in particular the plant's age, ontogenesis stage, agroprocessing methods, climatic conditions, plants pathogenic organisms and viruses contamination etc. Besides, growth regulators application during the clonal microreproduction in vitro, in turn, is capable of changing the intensity and character of plants' tissues metabolism, but does not cause considerable qualitative differences in these plants landed in vivo essential oil composition, which can be caused by specific fermental systems work stability and genes expression which are responsible for terpenoid synthesis regulation.

It is established by us that yield of essential oil increases in improved plants after methods of tissues and organs culture, chemotherapy in vitro and clonal microreproduction application. Improvement of the plants in culture in vitro can be considered as the reason for this increase in yield. As a clonal microreproduction result, better planting material was received, with better sprout tillering, their leaf cover and accordingly considerable inflorescences quantity, and, as is known (Oceania et al., 2015), intensive second level sprouts development and their dense flowering lead to increase in content of essential oil ketones (Tanasienko, 1985). From Fejer et al. (2018) article it is known that $0.5 \mathrm{mg} / \mathrm{l}$ cytokinin BAP addition increases sprouts quantity de novo.

Our research found that the quantity of menthol increased in all plants after culture in vitro application, which concurs with the findings presented in Santoro et al. (2013) publication, which studied growth regulators' influence on Mentha piperita plants in vitro aiming at growth and essential oil synthesis maximalisation in microreproducted plantsregenerants. Base nutrient medium was supplemented with 4-indolil-3- 
acetic acid (IAA) and BAP separately and in combination in our experiment. Only BAP in $0.6 \mathrm{mg} / \mathrm{l}$ concentration addition had led to the highest roots length, their dry weight, sprouts length and internode number, leaves and branching values. Only $0.6 \mathrm{mg} / \mathrm{I}$ IAA or simultaneously IAA and $0.6 \mathrm{mg} / 1 \mathrm{BAP}$ processing led to increase in sprouts weights by $50 \%$. Secondary metabolites synthesis increased only in the case of BAP addition,which resulted in $40 \%$ increase in the general yield of essential oil and the basic components (menthone, menthol, pulegone and menthofuran).

Fluctuations in menthol and menthone quantity of different breeds of peppermint were caused by plant genotype, and also connected with continuous synthesis processes, their biochemical transformation and evaporation. Menthone synthesis can occur by pulegone or piperitone restoration, and also in the course of menthol oxidation. Thus, the rather high accumulation of menthone content in the breeds Ukrainska Perechna and Chornolista specifies that for these two breeds there is high activity of fermental systems, which are involved in menthone synthesis pulegone ways.

We have confirmed the precise tendency of menthol to increase by $0.6-5.8 \%$ in essential oil of peppermint plants to which we applied culture in vitro, which corresponds to the research of Paric et al. (2017) which has revealed secondary metabolites production stimulation as a result of BAP in concentration from 0.1 to $4.0 \mathrm{mg} / \mathrm{l}$ and $0.1 \mathrm{mg} / \mathrm{l}$ indole3-butyric acid (IBA) separately and in combination application, which underlines the great value of the optimum growth regulator and its concentration choice. Also, we have verified that their application led to increase in sprouts and roots quantity.

In the publication of Ivanova et al. (1996) it is shown that menthol and menthone production reduces in plants after culture in vitro, to which cytokinins from purine and phenyl carbamide preparations were applied, but they led to increase in the amount of pulegone and menthofuran, and the highest pulegone content was observed after BAP application. In our research an insignificant increase in pulegone content was characteristic only for the breed Chornolista. Other investigated pepper mint breeds before and after improvement did not contain pulegone, which testifies to the absence of this component in the biochemical essential oil synthesis chain of peppermint plants of Ukrainian selection most likely this is caused by their genotype.

Also, in an article by Slovak scientists culture of M. piperita breed Kristinka in vitro is described, where they had cultivated node segments on nutrient medium and showed that after BAP and zeatin addition in the nutrient medium, the pulegone content increased, and after 2.4-D and $\mathrm{CoCl}_{2}$ application, menthofuran content in the essential oil composition increased. Our research found that menthofuran was present at $0.2 \%$ in the essential oil of cloned plants of the pepper mint breed Lidiya, though in vegetatively reproduced plants this component was absent. In all other investigated breeds at the same time a general tendency was observed to reduction in menthofuran content on the average by $0.2-2.5 \%$.

Thus, it is established that two components - menthol and menthone are the predominant components of the essential oil of plants of the breeds Lebedina Pisnya, Lubenchanka and Mama, and their total content was: Lebedina Pisnya - 82.9-85.0\%, Lubenchanka - 77.3-77.7\%, Mama $-82.5-84.6 \%$. In the essential oil of plants of the breed Lidiya three components - menthol, menthone, isomenthone - prevail, and their total content is $89.1-90.6 \%$; in the breed Ukrainska Perechna five compounds - menthone, menthyl acetate, menthofuran, menthol, pulegone prevail, and their total content is $68.9-81.1 \%$; in the breed Chornolista four compounds - menthone, menthol, isomenthol and pulegone prevail, and their total content is $69.9-70.1 \%$ from the total essential oil indices sum.

Menthol, menthyl acetate, cineole and menthone should be present in peppermint leaves (Peppermint leaf) according to the European pharmacopoeia. Also, isomenthone, pulegone and carvone can be determined on a chromatogram. Thymol presence is not required. The optimum for peper mint essential oil components (Peppermint oil) has to be in the proportion - limonene from 1.0 to $5.0 \%$, cineole $3.5-14.0 \%$, menthone $14.0-32.0 \%$, menthofuran $1.0-9.0 \%$, isomenthone $1.5-10.0 \%$, menthyl acetate $2.8-10.0 \%$, menthol $30.0-55.0 \%$, pulegone maximum of $4.0 \%$, carvone no more than $1.0 \%$, isopulegol no more than $0.2 \%$ according to European pharmacopoeia standards (Ph. Eur. 8, 2014).

The breed Lidiya was the most productive among the investigated breeds in 2015-2017, its indices were at 2,820 kg/ha level after improvement in vitro and $2,620 \mathrm{~kg} / \mathrm{ha}$ in the control group. Increase in raw materials productivity after improvement was minimal for the breed Lidiya among investigated breeds and was 7.6\%. This can be explained by the fact that culture in vitro and chemotherapy promote mainly the plants' improvement, protecting their tissues from pathogenic and potentially pathogenic microorganisms, endophytic and epiphytic mushrooms and viruses. Besides, according to existing data, pepper mint breed Lidiya plants have complex resistance to illnesses, which was confirmed in Mishhenko et al. $(2015,2016)$ publications concerning this breed's resistance to powdery mildew, rust, anthracnose and to virus diseases.

Differences in productivity indices in breeds Chornolista and Lebedina Pisnya between variants are essential and accordingly are $51.4 \%$ and $37.1 \%$. Owing to improvement, culture productivity considerably increased and was 2,120 kg/ha for breed Lebedina Pisnya and 2,550 $\mathrm{kg} / \mathrm{ha}$ for breed Chornolista. The last is one of the oldest peppermint breeds cultivated in Ukraine, which was created over thirty years ago and for a long time was cultivated in manufacture conditions. The breed Ukrainska Perechna increased productivity by $34.9 \%$, and breed Mama by $26.6 \%$, and this was 1,880 and $2,380 \mathrm{~kg} /$ ha accordingly.

Productivity indices analysis by air-dry foliage weight and pepper mint essential oil quantity determined that in plants after culture in vitro, in comparison with vegetatively reproduced plants, the essential oil quantity per hectare considerably increased in the breed Chornolista by 54.2\%, Lebedina Pisnya - by $38.2 \%$, Ukrainska Perechna - by $36.7 \%$, Mama - by $28.5 \%$, Lubenchanka - by $17.1 \%$, Lidiya - by $11.6 \%$.

Thus, the characteristic features of the investigated peppermint breeds of Ukrainian selection are the high menthol content, low carvone, piperitone, pulegone (except breeds Chornolista, Ukrainska Perechna) and menthofuran (except breeds Chornolista, Ukrainska Perechna and Lubenchanka) content. It is necessary to specify, that in the essential oil samples of the breeds Lebedina Pisnya, Lubenchanka, Lidiya and Mama pulegone was completely absent, and in essential oil samples of vegetatively reproduced plants of the breed Mama and both samples from the breed Lebedina Pisnya carvone was absent, which is caused by breed-specific genotypic features and action of fermentative systems, which are connected with given components synthesis.

\section{Conclusions}

The qualitative composition of essential oil of vegetatively reproduced peppermint plants raw materials and plants after culture in vitro essentially does not differ and it is within the measures which are characteristic for their genotypes. All raw material samples of improved peppermint plants had increased essential oil quantity. The maximum essential oil content exceeding 4\% was received from vegetative raw materials of the breed Lubenchanka. The componental composition of essential oil of mint which was received from vegetatively reproduced plants and plants after culture in vitro varies depending on the breed. In improved in vitro plants a clear tendency to increase in menthol and menthone content is revealed.

A high content of menthol (except for Chornolista, Ukrainska Perechna breeds), and low content of menthofuran (except for Chornolista, Ukrainska Perechna and Lubenchanka breeds) and of carvone, piperitone, pulegone (except the breeds Chornolista and Ukrainska Perechna) are characteristic for the investigated breeds of Ukrainian selection pepper mint. Pulegone was not detected in essential oil samples of the Lebedina Pisnya, Lidiya and Mama breeds. In the Lebedina Pisnya, Lubenchanka and Mama breeds the dominant components which differentiate them in the group of investigated breeds, are limonene, piperitone, menthol; for the Ukrainska Perechna and Chornolista breeds - pulegone, cineole and menthone; for Lidiya breed - iso-menthone.

As a result of clonal microreproduction in culture in vitro of pepper mint plants and improvements by virocide Ribavirin (1- $\beta$-D-ribofuranosyl-1.2.4-triazole-3-carboxamide, "Sigma-Aldrich", USA), the essential oil, in comparison with vegetatively reproduced plants, increased per 
hectare in the breed Chornolista by $54.2 \%$, Lebedina Pisnya - by $38.2 \%$, Ukrainska Perechna - by $36.7 \%$, Mama - by $28.5 \%$, Lubenchanka - by $17.1 \%$ and in Lidiya - by $11.6 \%$.

\section{References}

Costa, A. G., Bertolucci, S. K. V., Chagas, J. H., Ferraz, E. O., \& Pinto, J. E. (2013). Biomass production, yield and chemical composition of peppermint essential oil using different organic fertilizer sources. Ciencia e Agrotecnologia, 37(3), 202-210.

Council of Europe (2014). European Pharmacopoeia 8th Edition (Ph. Eur. 8). Strasbourg.

Dmitrieva, V. L., \& Dmitriev, L. B. (2011). Izuchenie sostava jefirnyh masel jefiromaslichnyh rastenij nechernozjomnoj zony Rossii [Study of the composition of essential oils of essential oil plants of the Non-chernozem zone of Russia]. Izvestija Timirjazevskoj Sel'skohozjajstvennoj Akademii, (3), 106-119.

Eshhenko, V. O., Kopitko, P. G., Kostogriz, P. V., \& Oprishko, V. P. (2014). Osnovy naukovykh doslidzhen' $\mathrm{v}$ agronomiji [Fundamentals of research in agronomy]. TD Edel'vejs \& K, Vinnytsya (in Ukrainian).

Fejer, J., Grul'ova, D., De Feo, V., Ürgeova, E., Obert, B., \& Pret'ova, A. (2018). Mentha $\times$ piperita L. nodal segments cultures and their essential oil production. Industrial Crops and Products, 112, 550-555.

Grigoleit, H.-G., \& Grigoleit, P. (2005). Pharmacology and preclinical pharmacokinetics of peppermint oil. Phytomedicine, 12, 612-616.

Grodzins'kij, A. M. (1992). Likars'ki roslyny: Enciklopedychnyj dovidnyk [Medicinal plants: An encyclopedic guide]. Ukrajins'ka enciklopedija imeni M. P. Bazhana, Ukrajins'kyj Vyrobnycho-Komercijnyj Centr Olimp, Kyiv (in Ukrainian).

Hefendehl, F. W., Underhill, R. W., \& Rudlof, F. (1967). The biosynthesis of the originated monoterpenes in mint. Phytochemistry, 6, 823-835.

Ivanova, K., Manov, M., Iliev, L., \& Stefanov, B. (1996). Effect of cytokinins on the essential oil composition of in vitro produced peppermint plants. Biotechnology and Biotechnological Equipment, 10(2-3), 4448.

Khanam, D., \& Mohammad, F. (2017). Effect of structurally different plant growth regulators (PGRs) on the concentration, yield, and constituents of peppermint essential oil. Journal of Herbs, Spices and Medicinal Plants, 23(1), 26-35.

Kirichenko, E. B. (2008). Ekofiziologija miaty: Produkcionnyj process i adaptacionnyj potencial [Ecophysiology of mint: Production process and adaptive potential]. Main Botanical Gardens Named after N. V. Tsitsin. Nauka, Moscow (in Russian).

Kolosovich, M. P., Shelud'ko, L. P., \& Kolosovich, N. R. (2008) Stvorennja bazovoji ta uchbovoji kolekciji m'jaty v Doslidnij stanciji likars'kyh roslyn [Creation of a basic and educational mint collection at the experimental station of medicinal plants]. Genetychni Resursy Roslyn, 2, 62-68 (in Ukrainian).

Lawrence, B. M. (2006). Mint: The genus Mentha. CRC Press Taylor \& Francis Group, Boca Raton, London, New York.

Magge, S., \& Lembo, A. (2011). Complementary and alternative medicine for the irritable bowel syndrome. Gastroenterology Clinics, 40(1), 245-253.

Mel'nichuk, M. D., Novak, T. V., \& Kunah, V. A. (2003). Biotehnologija roslyn [Biotechnology of plants]. Poligrafkonsalting, Kyiv (in Ukrainian).

Mi-Hyun, K., Eun-Hye, C., Hang-Sook, C., \& Kwang-Geun, L. (2005). Antioxidative activity of volatile extracts isolated from Angelica tenuissimae roots, peppermint leaves, pine needles and sweet flag leaves. Journal of Agricultural and Food Chemistry, 53(10), 41244129.

Mishhenko, L. T., Kucenko, N. I., \& Talankova-Sereda, T. E. (2016). Osobennosti diagnostiki virusnyh boleznej (Mentha piperita L.) i optimizacija mikroklonal'nogo razmnozhenija dlja ozdorovlenija [Features diagnosis of viral diseases of (Mentha piperita L.) and optimization of microclonal breeding for improvement of plants]. Sbornik nauchnyh trudov Mezhdunarodnoj nauchnoprakticheskoj konferencii "Biologicheskie osobennosti lekarstvennyh i aromaticheskih rastenij i ih rol' v medicine". Shherbinskaja Tipografija, Moscow. Pp. 282-287 (in Russian).

Moloc'kij, M. J., Vasil'kivs'kij, S. P., Knjazjuk, V. I., \& Vlasenko, V. A. (2006). Selekcija i nasinnyctvo sil's'kogospodars'kyh roslyn [Selection and seed production of agricultural plants]. Vishha Osvita, Kyiv (in Ukrainian).

Morozov, A. I., \& Hazieva, F. M. (2013). Biomorfologicheskie osobennosti i sroki uborki u sortov Mentha piperita L. raznogo celevogo naznachenija [Biomorphological features and harvesting time in Mentha piperita L. varieties of different designation]. Agricultural Biology, 1, 113-118 (in Russian).

Murashige, T., \& Skoog, F. A. (1962). Revised medium for rapid growth and bio assay with tobacco tissue culture. Plant Physiology, 15(3), 473-497.

Mishhenko, L. T., Dunich, A. A., Dashhenko, A. V., \& Polishhuk, V. P. (2015). Virusni hvoroby likars'kyh roslyn [Viral diseases of medicinal plants]. Fitosociocentr, Kyiv (in Ukrainian).

Oceania, C., Doni, T., Tikendra, L., \& Nongdam, P. (2015). Establishment of efficient in vitro culture and plantlet generation of tomato (Lycopersicon esculentum Mill.) and development of synthetic seeds. Journal of Plant Sciences, 10(1), 15-24.

Paric, A., Karalija, E., \& Cakar, J. (2017). Growth, secondary metabolites production, antioxidative and antimicrobial activity of mint under the influence of plant growth regulators. Acta Biologica Szegediensis, 61(2), 189-195.

Santoro, M. V., Nievasv, F., Zygadlo, J., Giordano, W., \& Banchio, E. (2013). Effects of growth regulators on biomass and the production of secondary metabolites in peppermint (Mentha piperita) micropropagated in vitro. American Journal of Plant Sciences, 4, 49-55.

Shelud'ko, L. P. (2004). M'jata perceva (selekcija i nasinnyctvo) [Mint pepper (breeding and seedling)]. Vydavnyctvo Poltava, Poltava (in Ukrainian).

Shelud'ko, L. P., \& Kucenko, N. I. (2013). Likars'ki roslyny (selekcija i nasinnyctvo) [Medicinal plants (breeding and seed production)]. Kopi-Centr, Poltava (in Ukrainian).

Talankova-Sereda, T. E., Kolomiec, J. V., \& Grigorjuk, I. P. (2016). Klonal'ne mikrorozmnozhennia sortiv m'jaty percevoji (Mentha piperita L.) Ukrajins'koji selekciji [Clonal micropropagation of peppermint (Mentha piperita L.) varieties of Ukrainian breeding]. Plant Varieties Studying and Protection, 2(31), 50-56 (in Ukrainian).

Tanasienko, F. S. (1985). Efirnye masla. Soderzhanie i sostav v rastenijah [Essential oils. Content and composition in plants]. Naukova Dumka, Kyiv (in Russian).

Tkachenko, K. G. (2011). Efirnomaslichnye rastenija i efirnye masla: Issledovanija i perspektivy, sovremennye tendencii izuchenija i primenenija [Essential oil plants and essential oils: Research and perspectives, modern trends in studying and application]. Bulletin of Udmurt University. Series Biology. Earth Sciences, 1, 88-100 (in Russian).

Vojtkevich, S. A. (1999). Jefirnye masla dlja parfjumerii i aromaterapii [Essential oils for perfumery and aromatherapy]. Food Industry, Moscow (in Russian). 